\title{
A Comparison Study Between the Suez Canal and the Panama Canal on the International Container Shipping
}

\author{
Prepared by \\ Khaled Gaber Abdalla El Sakty \\ College of International Transport and Logistics, \\ Arab Academy for Science and Technology and Maritime Transport, \\ Cairo, Egypt; \\ $\underline{\text { Khaled.sakty@aast.edu }}$ \\ Scientific Journal for Financial and Commercial Studies and \\ Researches (SIFCSR) \\ Faculty of Commerce - Damietta University \\ Vol.1, $\mathcal{N}$ o.2, Part 2., guly 2020
}

APA Citation:

El Sakty, K. G. A. (2020). A Comparison Study Between the Suez Canal and the Panama Canal on the International Container Shipping. Scientific Journal for Financial and Commercial Studies and Researches (SJFCSR), Vol.1 (2) Part2. pp.81-108

Website: https://cfdi.journals.ekb.eg/ 


\title{
A Comparison Study Between the Suez Canal and the Panama Canal on the International Container Shipping
}

\author{
Khaled Gaber Abdalla EI Sakty
}

\begin{abstract}
In a maritime context, locations of ports have a level of accessibility, but some are more accessible than others. Thus, some locations are perceived as more valuable than others, and more or less locations enhance the global container shipping flows than others. Visualising the worldwide maritime flow requires understanding the flows of the shipping networks, where the Canals impact the shipping lines' choices and ports' expansion plans. Two canals are selected for this purpose, namely the Suez Canal and the Panama Canal due to their significance in world seaborne trade and to their strategic locations. Therefore, this paper aims to compare the influence of the Suez Canal and the Panama Canal on the international container shipping. Graph theory in transport systems is applied as a methodology using geographic accessibility measure. The main finding is that the Suez Canal provides a more accessibility to a higher number of dominant hub ports than the Panama Canal.

Key Words: Accessibility measure, Connectivity matrix, Panama Canal, Suez Canal.

\section{1- Introduction}

In early 2019, total world fleet capacity reached 1.9 billion dead weight tons (UNCTAD 2019). The world commercial fleet consisted of 94,171 vessels, where dry bulk carriers, carrying iron ore, coal, grain and similar cargo, account for the largest share of the world fleet by 26.7 per cent in total gross tonnage and the largest share of total cargo-carrying capacity. They are followed by oil tankers account for 25 per cent of total dead-weight tonnage.
\end{abstract}




\section{Khaled Gaber Abdalla EI Sakty}

The third largest fleet is container ships, which account for 23.5 per cent and gas carriers by 13 per cent of the total gross tonnage (UNCTAD 2019). Container fleet supply capacity rose by 6 per cent in 2018, surpassing 2.6 per cent growth in containerised seaborne trade. To cope with such an increase in both the fleet-capacity and overall market conditions, the liner shipping industry witnessed further consolidation through mergers and acquisitions.

This growth of handled throughputs at ports requires reliable scheduled services between destinations. Therefore, liner shipping, acting as the distribution channel, is the mass transit system of the ocean ways with regular scheduled services of varying capacity between geographical regions. The growth of the liner shipping services is concerned about movements of freight, people and information. It seeks to link spatial constraints and attributes with the origin, the destination, the extent, the nature and the purpose of movements. This is known as a transport geography that is a sub-discipline of geography (Rodrigue et al. 2016).

In a transport geography, all geographic locations have a level of accessibility, but some are more accessible than others. Thus, some locations are perceived as more valuable than others, and more or less locations enhance the global shipping flows than others. This is because the demand they serve, their strategic locations along the geographic network and the number of links they connect. This is expressed by the complexity and structure of transportation networks. Accessibility is a key element to transport geography, and to geography in general, since it is a direct expression of mobility either in terms of people, freight or information. Also, contemporary economic processes have been accompanied by a significant increase in mobility and higher levels of accessibility. In addition to this, the most basic measure of accessibility involves network connectivity. Both accessibility and connectivity play indispensable roles by providing better economic opportunities through eliminating space and time constraints. The majority of location theories have an explicit or implicit role attributed to transport since accessibility is an important factor in the location preferences of shipping lines and operators. 
As a research motivation and important contribution to the field of transportation, this paper aims to compare the influence of the Suez Canal and the Panama Canal on the global container shipping. As a significant advance over the previous work published, graph theory in transport systems is applied as a methodology using measurable data to formulate facts about the connectivity and accessibility. The graph theory is used since it measures the flow of a network depending on the layout of nodes and links, and it also reveals the connectivity of a network in the best possible way (Rodrigue et al. 2016).

The rest of the paper is organised as follows. In section two, the paper reviews the related literature concerning the Suez Canal and the Panama Canal in the international container shipping. The research problem and methodology are discussed in section three. In section four, compare the influence of the Suez Canal and the Panama Canal on the global container shipping takes place. The findings and conclusion take place in section five.

\section{2- Literature Review}

A set of interoceanic Canals play an indispensable role in enhancing the flow of seaborne trade in the global networks. Interoceanic Canals are thus accurate markers of global trade and shipping activity (Ducruet 2016). From a network perspective, a range of hubs has common characteristics in terms of nautical accessibility and connectivity in shipping networks. Nevertheless, the hub ports strategic role in the global shipping networks depends on their locations near main passageways such as Suez Canal and Panama Canal. Therefore, competitiveness between the Cape route versus the Suez route has conducted based on a distance analysis, time consumption and cost analysis (Notteboom, 2012).

A set of challenges facing the Suez Canal has been identified such as piracy, the Canal's capacity, bunker price and macro-economic geography coverage. Ducruet and Notteboom (2012) claimed that the Suez and Panama Canals underline the strong vulnerability of the global network due to their high centrality in the global maritime supply chain. Therefore, they developed a map showing the nodal maritime regions of the world where the strong influence of geographic proximity and distance on the distribution of traffic are explained. 
Furuichi and Otsuka (2015) provided a comparative analyses of estimated shipping cost components via the North Sea Route (NSR) and Suez Canal, including capital cost and depreciation cost, NSR fee, Ice pilot fee, Suez Canal fee, Panama Canal fee, crew cost, maintenance cost, insurance cost, fuel cost, and port dues. It is concluded that the reduced transport time via the NSR is a significant advantage against Suez Canal, especially for the high-value cargoes. Shibasaki et al. (2016) compared the competitive environment of the Suez Canal with other competitive routes, using an aggregated logit model that described the shares of each route. The model focused on the supply side of the container shipping market, specifically, monetary shipping cost and time. It is claimed that the Suez Canal enhances the flow of container shipping on a global scale as it provides less costs and distances between Asia and Europe.

Wang et al. (2018) assessed the impact of opening of the NSR on the Suez Canal Route by means of discrete choice model to predict company's choices. Solvang et al. (2018) discussed the potential benefits for the Scandinavian economy and ports through the implementation of (NSR) as an alternative for container shipping to the established Southern route through the Suez Canal. In comparison with the Suez Canal, Zhu et al. (2018) discussed the NSR's impacts on environment versus its economic benefits on container shipping.

Zhang et al. (2016) claimed that North Sea Route (NSR) shipping is not economically favoured compared to Asia-Europe shipping route via Suez Canal in container shipping. Regarding the geographic coverage, Shibasaki et al. (2017) addressed global route choices for dry bulk carriers, focusing on the competitive situation between the Suez Canal and the Panama Canal (PC) and the route via the Cape of Good Hope, using a shortest-path model. (Pagano et al. (2016) and Wang (2017) claimed that Panama canal's expansion will generates more toll revenue for Panama government by allowing mega-vessels to transit. Liu et al. (2016) claimed that the enlarged ship size passing through the PC will increase the East Coast players' market power by $32 \%$ while hurting the West Coast players by $22 \%$.

Pham et al. (2018) illustrated the ranking of the three alternative routes, and it appeared that the shipping route from Hong Kong to New York via the Panama Canal is preferred by liner shipping companies, followed by the intermodal route via the Suez Canal and the U.S based 
on transportation costs factor. Regarding the network connectivity in the global container shipping, Wu et al. (2019) highlighted that East Asian and European container liner shipping have more than 50\% dependence on the Malacca Strait and the Suez Canal. Wu et al. (2019) measured the impact of interruption in the network's connectivity of the Malacca Strait, the Suez Canal and the Panama Canal, using the network weekly total shipping capacity. Yuan et al. (2019) examined the operational resilience of container lines to evolving traditional shipping networks such as Suez Canal and new routes such as Kra canal.

Fan and Gu (2019) examined the impact of the Panama Canal expansion on the container shipping route network, where the largest 15,000 TEU container ship is currently deployed on the route through the Panama Canal. Sun et al. (2020) evaluated the economic impact of the new shipping routes in the Arctic on the containerised flow worldwide, using a Spatial Computable General Equilibrium (SCGE) method. Van Hassel et al. (2020) examined the geographic coverage impact of the expanded Panama Canal on potential shifts of cargo flows on international shipping routes between the US, Asia and Europe. Ducruet et al. (2020) described the properties of the global container shipping using inter-port vessel movement data between (1977-2016), where graph theory and complex network methods are recommended to discuss the network's structures.

\section{3- Research Problem and Methodology}

\subsection{Research Problem}

In a maritime context, ports benefit from being connected to multiple commodity flows in the maritime networks. Within a network, ports and their links are affected by traffic volume, centrality and clustering. The structure of maritime networks is discussed in term of distance, flow intensity, port traffic, and port throughput. However, the application of wider network theories to global maritime networks is limited (Ducruet and Notteboom 2012).

On the other hand, it is widely acknowledged that the two major Canals, Suez and Panama Canals, play a central role in global container shipping flows ( $\mathrm{Wu}$ et al. 2019). As graph theory is a symbolic representation of a maritime network and of its connectivity, as it implies an abstraction of the reality so it can be simplified as a set of linked nodes (Calatayud et al. 2017). In this context, the research problem 
investigated in this paper can thus be addressed as 'Comparing the influence of the Suez Canal and the Panama Canal on the global container shipping'.

\subsection{Research Methodology}

Several research approaches have been applied in transport literature to measure the connectivity and accessibility of transit networks. But, the application of graph theory is rarely seen in the maritime literature in general, and in comparing the influence of the Canals in particular (Frazila and Zukhruf 2015). As a methodology, this research paper applied graph theory-based approach; this is to provide indices of how can the Canals be compared. For the national strategic policy making purposes in Egypt and in Panama, this will help understand the importance of the selected Canals, and to highlight the future needs such as expansion, deeping, etc. Figure 1 shows the research approach applied in this paper. Each step of the research approach is discussed as follows:

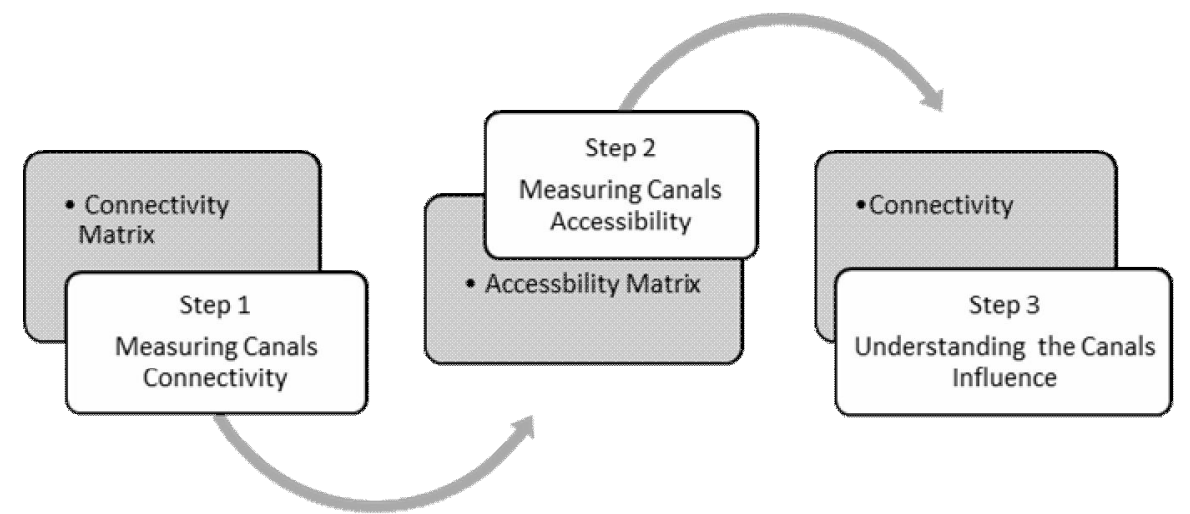

Figure 1. Research Approach

\subsubsection{Connectivity Matrix of the Canals}

In transport geography, there are several structures of transport networks for movement of people and freight between locations, which are based on key elements such as the origin and destination. In such a structure, Canals help to enhance the flow of movement of people and freight. Accessibility is one of the key measures of the Canals' influence on world container shipping since it represents the mobility of people and freight, and it measures the capacity of a location to be reached by, and it 
considers the locations and the distance between locations. As a first step in the research approach, the most basic measure of accessibility involves network connectivity where a network is represented as a connectivity matrix $(\mathrm{Cm})$, which expresses the connectivity of each node with its adjacent nodes. This can be represented as follows:

$C_{m}=\sum_{j}^{n} c_{i j}$

Where,

$\mathrm{Cm}=$ means connectivity matrix

$c_{i j}=$ refers to connectivity between location $i$ and location $j$

$n=$ refers to the number of nodes.

\subsubsection{Accessibility Matrix of the Canals}

Since efficient transportation systems offer high levels of accessibility, accessibility is defined as the measure of the capacity of a location to be reached by, or to reach different, locations. Geographic accessibility is applied as a highly practical measure where it considers that the accessibility of a location is the summation of all distances between other locations divided by the number of locations. The lower its value, the more a location is accessible. As a second step in the research approach, geographic accessibility cab be presented by the following equation:

$$
\mathrm{A}(\mathrm{G})=\sum_{\mathrm{i}}^{\mathrm{n}} \sum_{\mathrm{j}}^{\mathrm{n}} \mathrm{d}_{\mathrm{ij}} / \mathrm{n}
$$

Where,

$d_{i j}=$ distance between place $i$ and $j$

$n=$ number of locations

\subsubsection{Panama Canal Influence}

Panama Canal is selected in this paper since it is located in Panama in Central America shortens the distance between the Atlantic and Pacific Oceans about $7000-9000$ miles. It is about $80 \mathrm{~km}$ long. Approximately 13 to 14 thousand vessels pass through the Canal every year. that is about $4 \%$ (300 million tons of cargo) of the world seaborne trade (Dávid and Piala ,2016). Most of them come from the USA and China. Voyage of vessels takes between 8 and 10 hours. The size limit of the lock chambers 
of the Panama Canal influence the dimensions of ships (Panamax ships) which can sail through the Canal. The locks chambers are 33.5 metres (110 feet) wide, 305 metres (1,000 feet) long, and on average they are 25.3 metres deep ( 83 feet). The maximum length of Panamax ships is 965 feet $(294,1 \mathrm{~m})$, their maximum beam is 39,5 feet $(12 \mathrm{~m})$ and the maximum draught is 106 feet (32,3) (Pancanal, 2019). Some parts of the Canal have been deepened, a new generation of lock chambers with reutilisation basins have been built on both sides of the Canal and Oceans. A new generation of vessels called New Panamax will be able to sail through the Canal after these lock chambers are put into operation. Hence, the geographic accessibility of the Panama Canal needs to be assessed, which this is the main purpose of this paper.

\subsubsection{Suez Canal Influence}

The Suez Canal provides a much shorter route between the North Atlantic and the Indian Ocean than the alternative route round the Cape of Good Hope. The Canal, which is located in the northeast part of Egypt, links the Mediterranean Sea at Port Said with the Red Sea at Suez. The present Canal is about 193 kilometres long; transit of vessels in both directions (bypasses) is possible in the length of $113.3 \mathrm{~km}$. The Canal is about 310 metres wide at the surface and from 205 to 225 metres wide at the depth of 11 metres. It is the longest canal without locks in the world and is navigable 24 hours a day (Suezcanal, 2019). The geographical position of the Suez Canal makes it the shortest route between East and West as compared with the Cape of Good Hope. The Canal route achieves saving in distance between the ports north and south of the Canal, the matter that is translated into other saving in time, fuel consumption and ship operating costs. The Canal consists of the canal / by pass and three lakes namely Lake Timsah, Great Bitter Lake and Small Bitter Lake. Traditionally, transit of vessels takes between 13 and 15 hours. The term Suezmax is used for ships which can sail through the Suez Canal. Their deadweight is up to 240 thousand tons and their maximal width is 46 metres. These ships also have some limitations such as:

- The draught - ships which draught is more than 20,1 metres (66 feet) cannot sail through the Canal,

- The air draft - ships which are higher more than 70 metres cannot sail because of the Suez Canal Bridge. 
Recently, a new Canal from $\mathrm{km} 60$ to $\mathrm{km} 95$ was constructed in addition to deepening and widening of the Great Bitter Lakes bypasses and Ballah by-pass, with a total length of $37 \mathrm{~km}$. Creating a new canal, parallel to the existing one, aims to maximise benefit from the present Canal and its by-passes, and double the longest possible parts of the waterway to facilitate traffic in the two directions and minimize the waiting time for transiting ships. The new Suez Canal is proposed to:

- Shorten the transit time from 18 hours to 11 hours for the southbound convoy

- Minimize the waiting time for vessels to become three hours at most instead of 8-11 hours, the matter that will cut down on trip cost and make the Suez Canal more attractive for ship owners

- Attract more ships to use the Suez Canal, and add to the Canal classification as an important international maritime route

- Increase the number of ships that the Canal can handle on a daily basis in order to cope with the expected growth of world trade

This will certainly reduce the time needed for the trip from one end of the Canal to the other, and will increase the numerical capacity of the waterway, in anticipation of the expected growth in world trade. A new Suez Canal will add to the importance of the Suez Canal, and will increase the influence if the Canal as a route of choice for ship owners. This is putting any alternative routes out of competition. This reflects the main purpose of this paper to examine the influence of the Suez Canal on global container shipping.

\subsection{Container Shipping Selection}

The purpose of this paper is to compare the influence of the Suez Canal and the Panama Canal on the global container shipping. Container shipping network has selected for this purpose. Since shipping lines have to design their liner services and networks in order to optimise ship utilisation and benefit the most from scale economies in vessel size, tracing the worldwide circulation of container vessels becomes a more precise method for measuring the weight of link (Ducruet and Notteboom 2012). Also, the extensive worldwide container shipping networks are key to globalisation and global supply chains. In term of value of world seaborne trade, containers account $52 \%$ of total values, followed by $22 \%$ 
of tankers, $20 \%$ of general cargo, and $6 \%$ of dry bulk (Worldshipping 2019). For the Canals, container ships constitute the main ship type and net tonnage cross for the Suez Canal, where its capacity is designed to accommodate $100 \%$ of container ships, $92.7 \%$ of bulk fleet, and $61.2 \%$ of tanker fleet (Suezcanal 2019). Also in Panama Canal, containers account the highest net tonnages cross the Canal (Pancanal 2019). Hence, this paper considers only container shipping lines as links in the measurement of Canals' influence.

\section{4- Measuring the Influence of the Suez Canal and Panama Canal}

In fact, the Suez Canal, Panama Canal, and other artificial waterways have powerfully shaped the global trade, while producing immense economic advantages worldwide (Chen et al., 2019). For instance, the ships engage into oceans and international trade via using sea connections. Those connections can be classified as natural connections and man-made connections. Also, they are classified as international connections, regional connections and major straight (Charlier et al., 2015). Both natural and man-made connections lead to high connectivity. Based on a shipping connectivity index developed by the UNCTAD, a density map of containers trade routes can be developed as shown in Figure 2. The density map helps illustrates the index trends in selected regions. In 2018, around 8 million TEUs of cargo are estimated to be transported on the transatlantic trade route, 25 million TEUs on Europe-Asia-Europe route, and 28 million TEUs on TransPacific trade route. However, the density map can mislead to comprehend the influence of the Suez and Panama Canals for the following reasons:

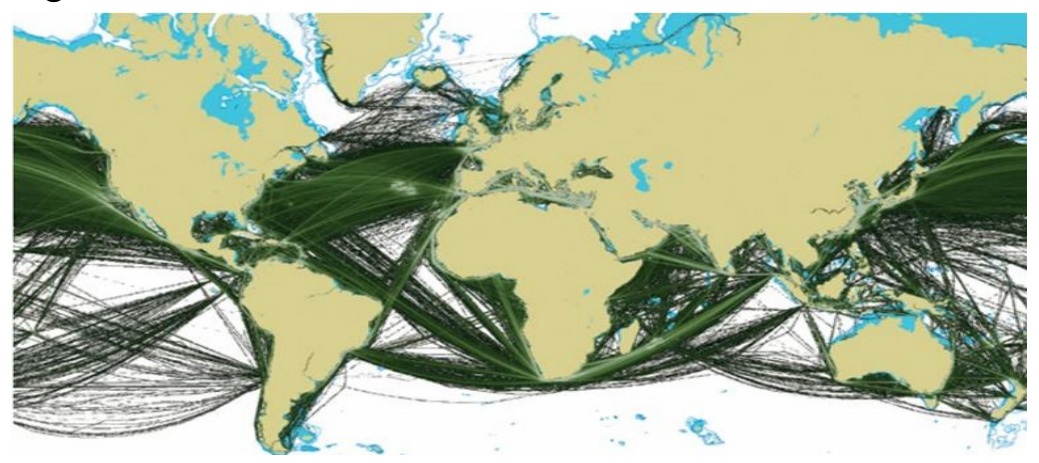

Figure 2- Density Map of Container Trade routes

Source: UNCTAD, 2017, p. 101. 
- Canal Connectivity (CC): countries and their ports can benefit from such Canal connectivity, while other countries located a long side the same Canal cannot benefit. For example, on the west coast of South America, Panama are the best-connected country benefits from the Panama Canal. The Canal has encouraged the establishment of transshipment ports. Chile and Peru have largely the same level of connectivity, as both countries are served by the same companies and ships. But, Ecuador is still lagging behind due to last to invest in ship-to-shore container gantry cranes and is hindered by draft restrictions in comparison with the other main ports on the west coast of South America.

- Container Deployment (CD): Container ship deployment to seaports in Egypt and Panama is similar overall, even though the maximum ship size that can pass through the Suez Canal is far larger than what is allowed through the Panama Canal, even after the latter's expansion. However, the larger ships that pass through the Suez Canal do not make use of Egyptian seaports.

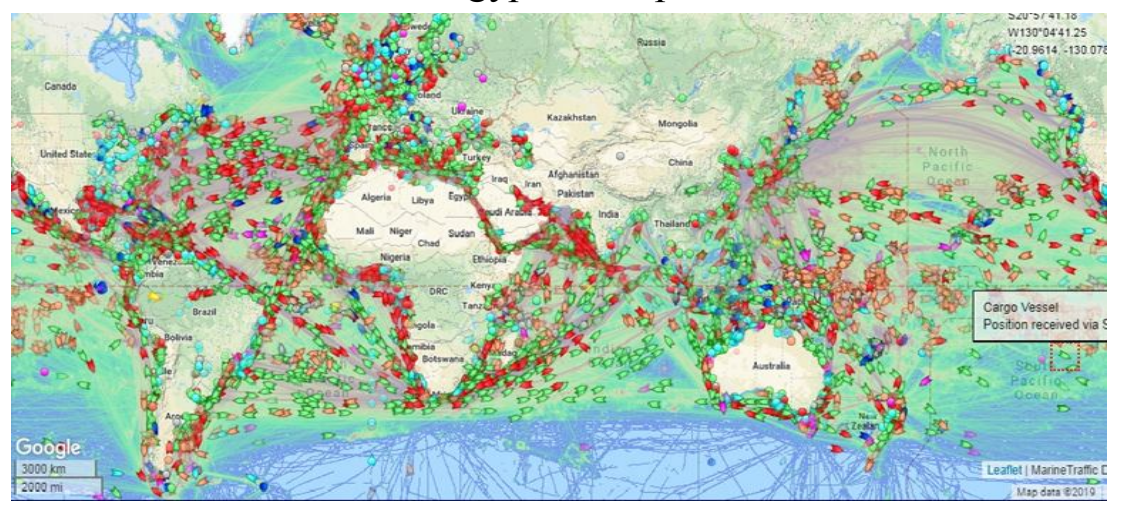

Figure 3- Marine Traffic Density Map in 12/1/2019

Source: www.marinetraffic.com, 2019

In fact, the marine traffic density map cannot articulate preciously the efficiency of the capacitated network designs of the Canals (see Figure 3). For example, a number of services called Egypt were 71 services in 2017, and 62 services called Panama. However, a number of ships scheduled on services called Panama were 357 in the same year, compared to 293 ships called Egypt (UNCTAD, 2017). Moreover, both countries with their Canals (Suez, Panama) were not included in the top 25 country pairs ranked according to the bilateral liner shipping 
connectivity in 2016. The future of shipping and ports is not only directed by future trade flows. It is more about how and under which conditions these flows will move globally within a supply chain perspective. The Canals play a vital role in enhancing the global flows of goods.

\subsection{Understanding Canals Influence on Global Container Shipping}

It is noticeable that the influence of the Canals does not depend on the number of nodes and links alongside the Canal route. The Suez Canal has the highest number of nodes and links, but it is claimed that it has the lowest influence value. This result is due to many factors. First, most of all linked pairs of ports are connected only in one direction; accordingly, the routes between ports become short. Second, most ports along the Suez Canal route have few connections, but there are few ports linked to hundreds of other ports, which affects its connectivity. Third, the types and characteristics of ships passing via the Suez Canal affect its complexity and efficiency. Container ships call much more frequently than bulk dry carriers and oil tankers. Fourth, the networking complexity increases by the nodes strengths. It is not necessary to have many ports (nodes) within a canal's geographic network as it is important to have high-level dominant ports such as hub ports. Finally, the length of the canal's links is directly concerned with various costs such as fuel, maintenance and insurance.

In fact, the locations of the Suez and Panama canals are affected by the maritime network system. Both locations are very polycentric around different poles, serving certain market areas. Many small and mediumsize ports are dominated by one major hub node that is acting as a centric pole (Arvis et al. 2018).

Therefore, it is important to measure the influence of the Canals with only high-level dominant ports such as hub ports. Considering only the hub ports will, of course, decrease the number of nodes in the networks of the Canals. The main hub dominant nodes (ports) for global containers networks have identified by the author through reviewing the top 100 hub container ports as shown in Figure 4, which are collected using Lloyd's list, revised by their ranking regarding their annual container throughput, and mapped as ranked in 2019. The top 100 container ports in 2019 have considered in this paper as hub dominant ports (lloydslist 2019). 


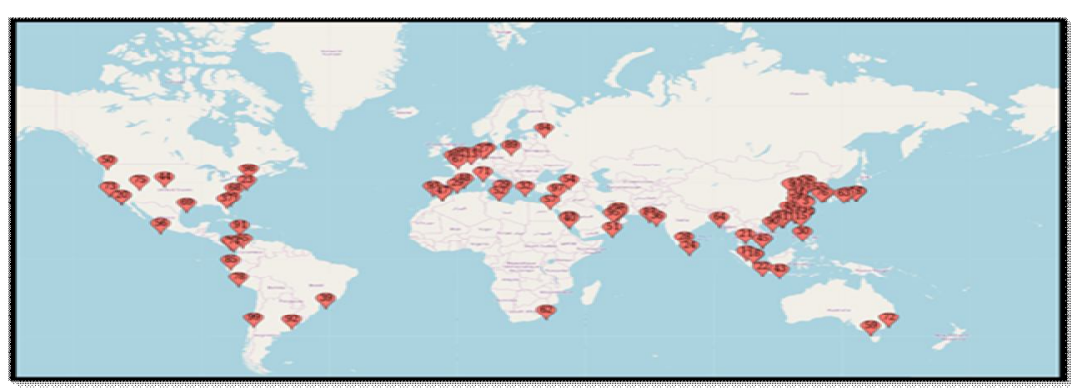

Figure 4- Map of Top 100 World Container Ports ranked by Capacity

Source: author's compilation based on data of lloydslist, 2019.

Note: A concrete network map has constructed by the author as shown in the Figure 4. The author has identified the top 100 world container ports, their coordinates have collected using a simple decimal degree standard coordinates (DD), and their locations have mapped manually by the author.

For the Suez Canal, it is evident that when excluding non-dominant ports increase its influence on global shipping. This is because hub ports have high frequency calls, regular scheduled calls, and attracting high capacity ships. This pattern leads to increasing the gravity of nodes (ports) and strengthening the capacitated links within the networking. In the Suez Canal, container ships are the highest type of ships crossing the canal with 53\% net tonnage by ship type in the first quarter of the year 2019.

For the Panama Canal, its influence on global container shipping is subject to many factors: first, the canal is a major passageway in the network of global shipping traffic linking the Atlantic and Pacific oceans. Second, widening and deepening the existing Canal channels doubled the capacity of the Canal and allowed transits of larger container ships. This increased capacity of the Panama Canal is likely to affect global trade routes (Muirhead et al. 2015). Also, the canal expansion project has contributed to transit time reduction and accommodation of larger vessels.

In order to visualise the canals' network, a concrete network map has constructed by the author as shown in the Figure 5. The 446 commercial ports have identified, their coordinates have collected using a simple decimal degree standard coordinates (DD), and their locations have mapped. This displays the links and passing ports (nodes) within 


\section{Khaled Gaber Abdalla EI Sakty}

every Canal network. For instance, every Canal has different number of nodes and links and a level of accessibility, but some are more accessible than others. Undoubtedly, a degree of accessibility differs from one Canal to another. Moreover, some canals have fewer links and nodes but great influence on the trade routes.

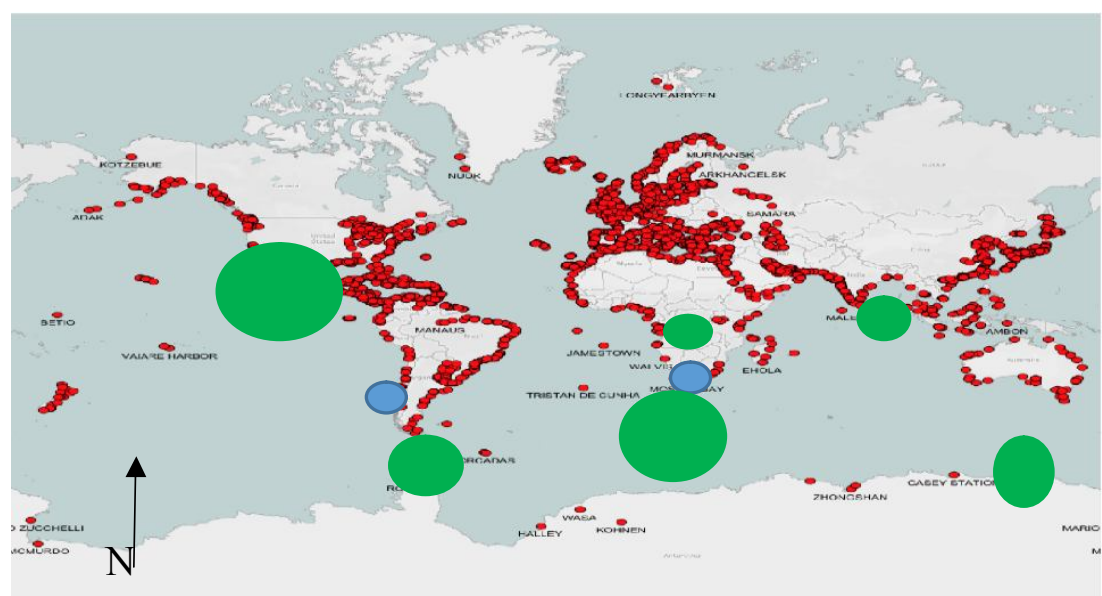

Scale: 1:20000 000

Figure 5. Interoceanic Canals and the Trade Networks (Links- Zones - Nodes)

Map Legend:

2 Canals 446 commercial Ports 7 Zones

Source: Author's compilation based on data of fleetmon.net; A concrete network map has constructed by the author as shown in the Figure 4 . The 446 commercial ports have identified, their coordinates have collected using a simple decimal degree standard coordinates (DD), and their locations have mapped.

\subsection{Connectivity Matrix Development}

There are several types of transport structures that are linked with Canals' networks. Those structures are identified with key elements such as nodes, links, flows, hubs, and the accessibility they provide to locations. Uninterrupted sequence of links between two nodes is a fundamental attribute in measuring connectivity and accessibility. This explains why some locations within a network have higher accessibility, which is often related to better opportunities. Measuring the network accessibility can be determined by the capacity of a location to reach or be reached by different locations. The most basic measure of accessibility 
Scientific Journal for Financial and Commercial Studies and Researches (SJFCSR) Faculty of Commerce - Damietta University

involves network connectivity where a network is represented as a connectivity matrix (Cm) (Rodrigue et al., 2016).

Table 1. Direct Connectivity Matrix with Hub Nodes

(a) $\mathrm{Cm}$ for Panama Canal

\begin{tabular}{|c|c|c|c|c|c|c|c|}
\hline Nodes & Co & Dis & $\mathrm{Gu}$ & $\mathrm{Ca}$ & Kin & Man & $\Sigma$ \\
\hline Col & 0 & 0 & 1 & 1 & 1 & 1 & 4 \\
\hline Dis & 0 & 0 & 0 & 0 & 0 & 1 & 1 \\
\hline Gua & 1 & 0 & 0 & 0 & 0 & 1 & 2 \\
\hline Car & 1 & 0 & 0 & 0 & 0 & 0 & 1 \\
\hline Kin & 1 & 0 & 0 & 0 & 0 & 0 & 1 \\
\hline Man & 1 & 1 & 1 & 0 & 0 & 0 & \\
\hline$\Sigma$ & 4 & 1 & 2 & 1 & 1 & & \\
\hline
\end{tabular}

(b) $\mathrm{Cm}$ for Suez Canal

\begin{tabular}{|c|c|c|c|c|c|c|c|c|c|c|c|c|c|c|}
\hline & Sal & Jed & Kia & Por & Mer & Pir & Gio & Mar & Bar & Val & Gen & Tan & Sin & $\Sigma$ \\
\hline Sal & 0 & 1 & 1 & 1 & 0 & 0 & 0 & 0 & 0 & 0 & 0 & 0 & 0 & 3 \\
\hline Jed & 1 & 0 & 1 & 1 & 1 & 1 & 1 & 0 & 1 & 1 & 1 & 0 & 0 & 8 \\
\hline Kia & 1 & 1 & 0 & 1 & 1 & 1 & 1 & 0 & 0 & 0 & 0 & 0 & 0 & 6 \\
\hline Por & 1 & 1 & 1 & 0 & 1 & 1 & 1 & 0 & 1 & 1 & 1 & 0 & 0 & 9 \\
\hline Mer & 0 & 1 & 1 & 1 & 0 & 1 & 1 & 0 & 0 & 1 & 1 & 0 & 0 & 7 \\
\hline Pir & 0 & 1 & 1 & 1 & 1 & 0 & 0 & 0 & 0 & 1 & 1 & 0 & 0 & 6 \\
\hline Gio & 0 & 1 & 1 & 1 & 1 & 0 & 0 & 0 & 0 & 1 & 0 & 0 & 0 & 5 \\
\hline Mar & 0 & 0 & 0 & 0 & 0 & 0 & 0 & 0 & 0 & 0 & 0 & 0 & 0 & 0 \\
\hline Bar & 0 & 1 & 0 & 1 & 0 & 0 & 0 & 0 & 0 & 0 & 1 & 0 & 0 & 3 \\
\hline Val & 0 & 1 & 0 & 1 & 1 & 1 & 1 & 0 & 0 & 0 & 1 & 0 & 0 & 6 \\
\hline Gen & 0 & 1 & 0 & 1 & 1 & 1 & 0 & 0 & 1 & 1 & 0 & 0 & 0 & 6 \\
\hline Tan & 0 & 0 & 0 & 0 & 0 & 0 & 0 & 0 & 0 & 0 & 0 & 0 & 0 & 0 \\
\hline Sin & 0 & 0 & 0 & 0 & 0 & 0 & 0 & 0 & 0 & 0 & 0 & 0 & 0 & \\
\hline$\Sigma$ & 3 & 8 & 6 & 9 & 7 & 6 & 5 & 0 & 3 & 6 & 6 & 0 & & \\
\hline
\end{tabular}

The networking connectivity of the two Canals is shown in Table 6 . As discussed earlier, it is found that the Canals networking connectivity is highly affected by the number of high-dominant nodes (hub ports). It is evident form that the high degree of networking connectivity of the Canals leads to the high networking complexity. The matrix among hub 
nodes can be estimated using the binary system (i.e, $0-1$ ), where the values equal with 1 refers to a direct connection between nodes, and 0 otherwise. It is obvious from table 1 that all nodes have not been connected each other by a direct connection. This is due to the hub and spoke behaviour on the maritime transport. In Table 6, abbreviations have been given to refer to those ports located in the Canals' networks, and the container shipping services between hub ports are reviewed by shipping lines connections and liner services. It is obvious that the Suez Canal has more connectivity than Panama Canal as shown in Table 1. The capacity of Suez Canal is higher to reach or be reached by more different locations than the Panama Canal. However, this is a basic accessibility measure (connectivity measure) that does not consider the distances between dominant hub ports.

Therefore, Rodrigue et al. (2016) proposed highly practical measure; namely geographic accessibility. Accessibility is applied in this paper as it considers that the accessibility of a location is the summation of all distances between other locations divided by the number of locations. The lower its value, the more a location is accessible.

\subsection{Accessibility Matrix Development}

Regarding the accessibility measurement, graph theory can be applied that is defined as a representation of the network structure in term of locations (nodes) and the connectivity between locations (links). The geographic accessibility has been developed by generating a distance grid for each hub node along the Suez Canal and the Panama Canal, and then summing all the grids to form the total summation of distances grid. The cell having the lower value is thus the most accessible place. How many most accessible places provided by each Canal can represent the most geographic coverage by the Canal. The construction of a geographic accessibility matrix takes two steps:

- Build the valued graph matrix to display the distance in kilometres between the hub nodes.

- Build the geographic accessibility matrix as shown in Table 2. The matrix displays the distances between ports using a nautical mile according to the geographical index developed by Lloyd's Maritime Atlas of World Ports and Shipping Places, where the speed is at 10 knots. 

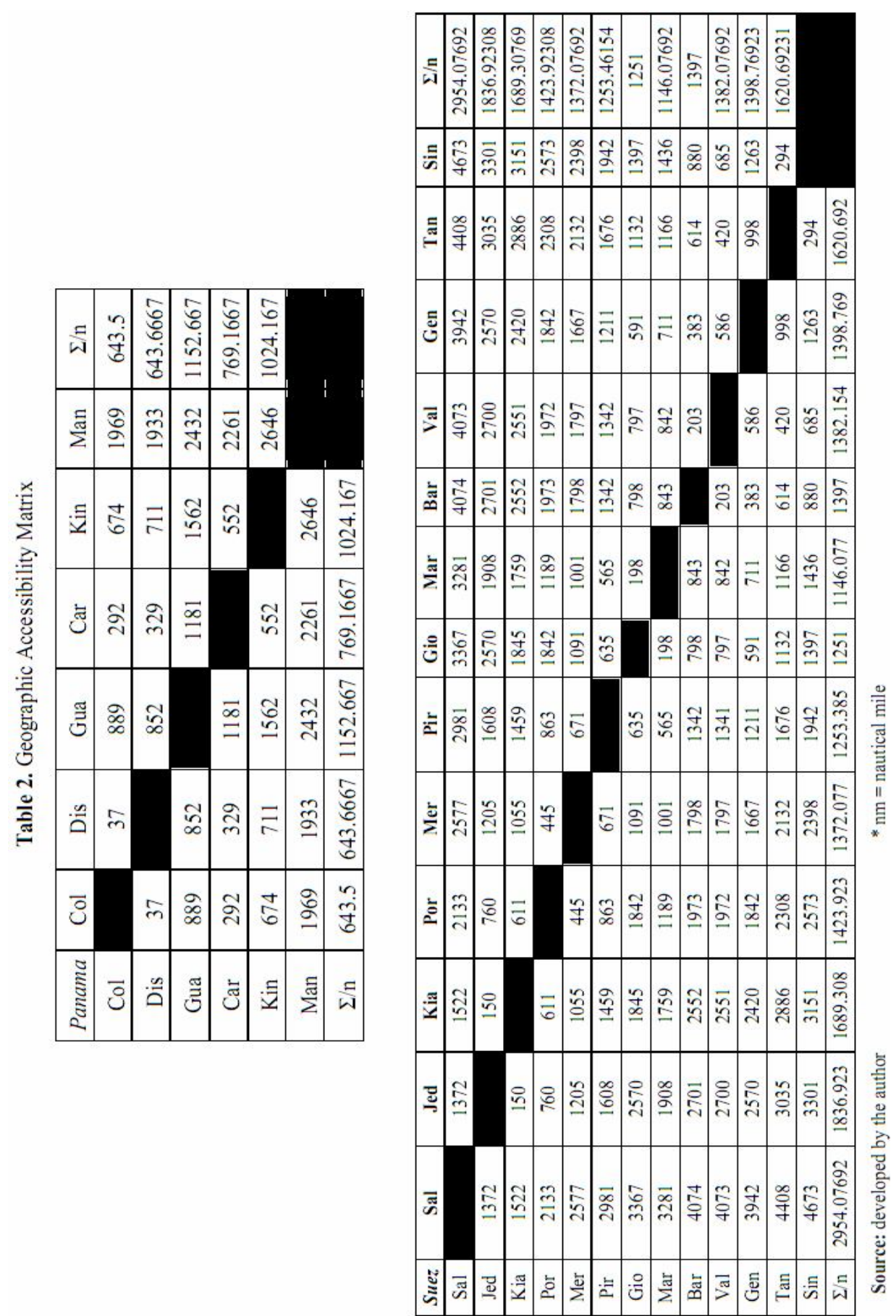


\section{Khaled Gaber Abdalla EI Sakty}

nautical mileIn fact, the accessibility in any network depends on the number of dominant nodes, distances between nodes, and the network structure. Table 2 shows that the Suez Canal has higher geographic accessibility than the Panama Canal for many reasons:

1. The Canal network includes a higher number of hub dominant ports compared to the Panama Canal;

2. It seems from the lower values of cells that Panama is more accessible, but this is justified as most of hub dominant ports are located nearby in Atlantic Ocean and Pacific Ocean. However, the Suez Canal provides shortest distances between those dominant ports located in Mediterranean Sea, Red Sea and Arab Sea.

3. It is evident that the Suez Canal provides more geographic accessibility, where the location of the Canal plays indispensable role in reaching different locations. 

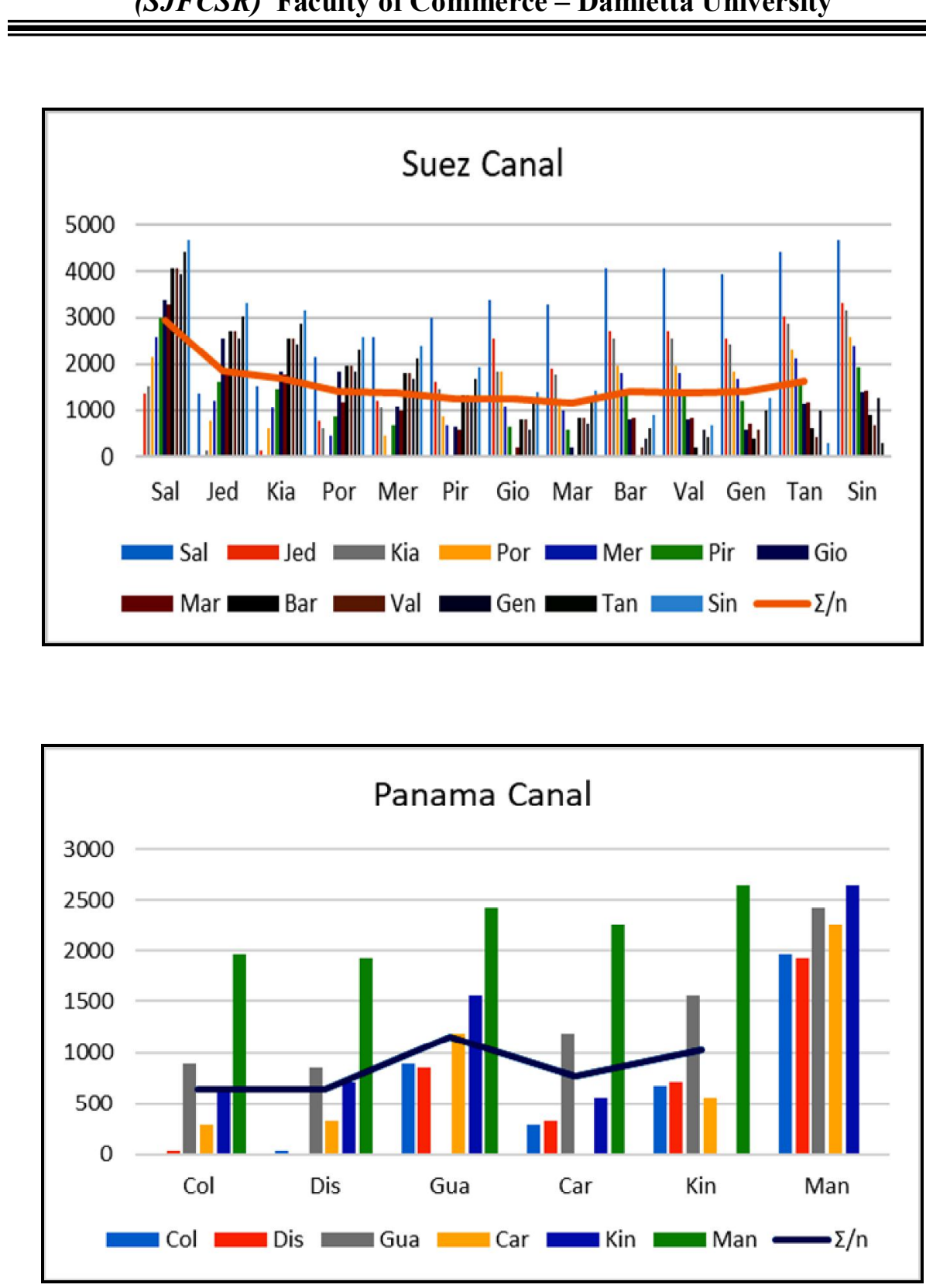

Figure 6- Canals Geographic Accessibility 
It is evident that the Suez Canal has high influence than the Panama Canal on the global container shipping since it serves the most important geographic locations as shown in Figure 6. Also, the Suez Canal has a good accessibility as it provides lower values regarding the accessibility matrix. This justifies why it is considered the shortest way between the East and West. Similarly, the Panama Canal provides a geographic accessibility for those ports located surrounding the Canal. In other words, each Canal provides a level of geographic accessibility for surrounding ports, but with different degree of accessibility. It depends on a number of factors including; the location of the Canal, a number of dominant hub ports located inside the Canal's network, and the distance between the dominant hub ports and the Canal. This summary helps understand the research question how the Suez Canal and Panama Canal can influence the global container shipping network.

\section{5- Findings and Conclusion}

The maritime industry is characterised as the most energy efficient mode which carries large quantities of goods for long distances. A highlevel description of the global maritime network does not fully capture the networks connectivity and accessibility. The influence of the Panama Canal and Suez Canal is examined in this paper relying on their connectivity and provision of geographic accessibility, rather than a networking capacity. It is evident that that the influnce of a Canal does not depend on the number of nodes and links along the Canal route. It depends on the number of the dominant hub ports and the strength of the links (connectivity) between ports. The Suez and Panama Canals usually receive high attention relying on their capacitated flows. Therefore, regarding the Canals accessibility measurement, it is marked that the number of dominant nodes affects the networking accessibility, too. It can be concluded that the Suez Canal provides more geographic accessibility than the Panama Canal where it provides connectivity to higher number of dominant ports. However, each Canal provides a level of geographic coverage for surrounding ports, but with different degree of accessibility.

As a practical implication, this paper helps to understand the weight of Canals-dependent flows. Besides, it helps cargo owners, shipping lines and ship owners understand the networking connectivity and accessibility 
of the interoceanic Canals, and plan the distribution flows of goods in the world shipping.

As a theoretical implication, the paper helps structure the global interoceanic networks according to their connectivity and accessibility. In turns, it provides a comprehensive overview of the design of the Canals and it illustrates how a number of dominant ports affect their coverage areas.

For further researches, this research approach can be generalised in future research comparing between other Canals. Also, a potential accessibility is recommended to take place in any future research. In addition, the geographic accessibility can be conducted for other types of cargoes rather than containers, such as bulk, oil and gas. 


\section{References}

Arvis, Jean-François, Vincent Vesin, Robin Carruthers, and César Ducruet. Maritime Networks, Port Efficiency, and Hinterland Connectivity in the Mediterranean. World Bank Publications, 2018.

Calatayud, Agustina, John Mangan, and Roberto Palacin. "Vulnerability of international freight flows to shipping network disruptions: A multiplex network perspective." Transportation Research Part E: Logistics and Transportation Review 108 (2017): 195-208.

Charlier, J., De Meyer, C. \& Paelinck, H., 2015. Interoceanic Canals and World Seaborne Trade: Past, Present and Future. International Colloquium. Port of Antwerp.

Chen, Jihong, Theo Notteboom, Xiang Liu, Hang Yu, Nikitas Nikitakos, and Chen Yang. "The Nicaragua Canal: potential impact on international shipping and its attendant challenges." Maritime Economics \& Logistics 21, no. 1 (2019): 79-98.

Dávid, A. and Piala, P., 2016. The strategic maritime canals and straits. Perner's Contacts, 11(2), pp.5-10.

Ducruet, C., Berli, J. and Bunel, M., 2020. Geography versus topology in the evolution of the global container shipping network (19772016). In Geographies of Maritime Transport. Edward Elgar Publishing.

Ducruet, César, and Theo Notteboom. "Developing liner service networks in container shipping." (2012).

Ducruet, César, and Theo Notteboom. "The worldwide maritime network of container shipping: spatial structure and regional dynamics." Global networks 12, no. 3 (2012): 395-423.

Ducruet, César. "Multilayer dynamics of complex spatial networks: The case of global maritime flows (1977-2008)." Journal of Transport Geography 60 (2017): 47-58.

Ducruet, César. "Network diversity and maritime flows." Journal of Transport Geography 30 (2013): 77-88.

Ducruet, César. "The polarization of global container flows by interoceanic canals: geographic coverage and network vulnerability." Maritime Policy \& Management 43, no. 2 (2016): 242-260. 
Fan, H. and Gu, W., 2019. Study on the Impact of the Panama Canal Expansion on the Distribution of Container liner routes. Journal of Transportation Technologies, 9(02), p.204.

Fraser, Darren Ronald, Theo Notteboom, and César Ducruet. "Peripherality in the global container shipping network: the case of the Southern African container port system." GeoJournal 81, no. 1 (2016): 139-151.

Frazila, Russ Bona, and Febri Zukhruf. "Measuring connectivity for domestic maritime transport network." Journal of the Eastern Asia Society for Transportation Studies 11 (2015): 2363-2376.

Furuichi, M. and Otsuka, N., 2015. Proposing a common platform of shipping cost analysis of the Northern Sea Route and the Suez Canal Route. Maritime Economics \& Logistics, 17(1), pp.9-31.

Hesse, Markus, and Jean-Paul Rodrigue. "The transport geography of logistics and freight distribution." Journal of transport geography 12, no. 3 (2004): 171-184.

Lioyd's list.com (2019). World Container Traffic Data 2018 [online] Available at: https://lloydslist.maritimeintelligence.informa.com/one-hundredcontainer-ports-2019/ [Accessed 29 Nov. 2019].

Liu, Q., Wilson, W.W. and Luo, M., 2016. The impact of Panama Canal expansion on the container-shipping market: a cooperative game theory approach. Maritime Policy \& Management, 43(2), pp.209221.

Muirhead, Jim R., Mark S. Minton, Whitman A. Miller, and Gregory M. Ruiz. "Projected effects of the Panama Canal expansion on shipping traffic and biological invasions." Diversity and Distributions 21, no. 1 (2015): 75-87.

Notteboom, Theo E. "Towards a new intermediate hub region in container shipping? Relay and interlining via the Cape route vs. the Suez route." Journal of Transport Geography 22 (2012): 164-178.

Pagano, A., Wang, G., Sánchez, O., Ungo, R. and Tapiero, E., 2016. The impact of the Panama Canal expansion on Panama's maritime cluster. Maritime Policy \& Management, 43(2), pp.164-178.

Pancanal.com (2019). Panama Canal Traffic by Market Segment 20192018 [online] Available at: 
https://www.pancanal.com/eng/op/transit-stats/2019/Table-09.pdf [Accessed 27 Oct. 2019].

Pham, Thi Yen, Ki Young Kim, and Gi-Tae Yeo. "The Panama Canal Expansion and Its Impact on East-West Liner Shipping Route Selection." Sustainability 10, no. 12 (2018): 4353.

Rodrigue, Jean-Paul. The geography of transport systems. Taylor \& Francis, 2016.

Secretariat, U.N.C.T.A.D. "Review of maritime transport 2017”. (2017) United Nations Pubns.

Secretariat, U.N.C.T.A.D. "Review of maritime transport 2019". (2019) [online] Available https://unctad.org/en/PublicationsLibrary/rmt2018_en.pdf [Accessed 3 Jan. 2020].

Shibasaki, R., Azuma, T. and Yoshida, T., 2016. Route choice of containership on a global scale and model development: focusing on the Suez Canal. International Journal of Transport Economics, 43(3).

Shibasaki, R., Azuma, T., Yoshida, T., Teranishi, H. and Abe, M., 2017. Global route choice and its modelling of dry bulk carriers based on vessel movement database: Focusing on the Suez Canal. Research in transportation business \& management, 25, pp.51-65.

Solvang, H.B., Karamperidis, S., Valantasis-Kanellos, N. and Song, D.W., 2018. An exploratory study on the Northern Sea Route as an alternative shipping passage. Maritime Policy \& Management, 45(4), pp.495-513.

Suezcanal.gov.eg (2019). Yearly number and Net Ton by Ship Type 2018 [online] Available at:https:/www.suezcanal.gov.eg/English/Navigation/Pages/Navigat ionStatistics.aspx [Accessed 27 Oct. 2019].

Sun, Zhuo, Ran Zhang, Yuan Gao, Zhongxing Tian, and Yi Zuo. "Hub ports in economic shocks of the melting Arctic." Maritime Policy \& Management (2020): 1-24.

Traffic, Marine. "'MarineTraffic: Global Ship Tracking IntelligenceAIS Marine Traffic." [online] Available at: https://www.marinetraffic.com/en/ais/home/centerx:12.0/centery:25.0/zoom:4 [Accessed 9 Jan. 2019]. 
Van Hassel, Edwin, Hilde Meersman, Eddy Van de Voorde, and Thierry Vanelslander. "The impact of the expanded Panama Canal on port range choice for cargo flows from the US to Europe." Maritime Policy \& Management (2020): 1-19.

Wang, H., Zhang, Y. and Meng, Q., 2018. How will the opening of the Northern Sea Route influence the Suez Canal Route? An empirical analysis with discrete choice models. Transportation Research Part A: Policy and Practice, 107, pp.75-89.

Wang, M., 2017. The role of Panama Canal in global shipping. Maritime Business Review.

Wang, Shuaian, Qiang Meng, and Zhuo Sun. "Container routing in liner shipping." Transportation Research Part E: Logistics and Transportation Review 49, no. 1 (2013): 1-7.

Weibin, D. A. I., Jun Zhang, and S. U. N. Xiaoqian. "On solving multicommodity flow problems: An experimental evaluation." Chinese Journal of Aeronautics 30, no. 4 (2017): 1481-1492.

Worldshipping.org. (2019). Trade Routes. World Shipping Council. [online] Available at: http://www.worldshipping.org/about-theindustry/global-trade/trade-routes [Accessed 20 Feb. 2019].

$\mathrm{Wu}, \mathrm{Di}$, Nuo Wang, Anqi Yu, and Nuan Wu. "Vulnerability analysis of global container shipping liner network based on main channel disruption." Maritime Policy \& Management 46, no. 4 (2019): 394409.

Yuan, C.Y., Hsieh, C.H. and Su, D.T., 2019. Effects of new shipping routes on the operational resilience of container lines: potential impacts of the Arctic Sea Route and the Kra Canal on the EuropeFar East seaborne trades. Maritime Economics \& Logistics, pp.118.

Zhang, Y., Meng, Q. and Ng, S.H., 2016. Shipping efficiency comparison between Northern Sea Route and the conventional Asia-Europe shipping route via Suez Canal. Journal of Transport Geography, 57, pp.241-249.

Zhu, S., Fu, X., Ng, A.K., Luo, M. and Ge, Y.E., 2018. The environmental costs and economic implications of container shipping on the Northern Sea Route. Maritime Policy \& Management, 45(4), pp.456-477. 


\title{
دراستمقارنت بين قناة السويس وقناة بنما على الشحن الدولي بالحاويات
}

\author{
د. خالد جابر عبد اللّه السقطي

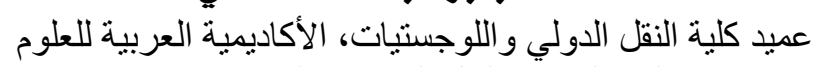

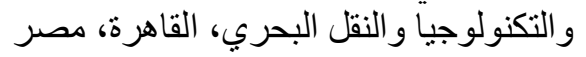 \\ Khaled.sakty@aast.edu
}

\begin{abstract}
ملخص البحث

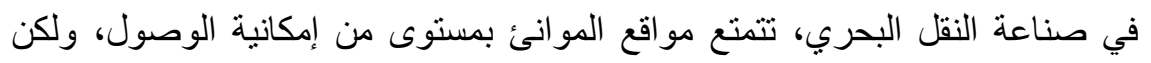

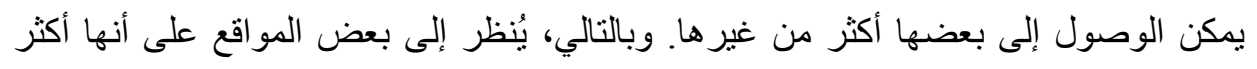

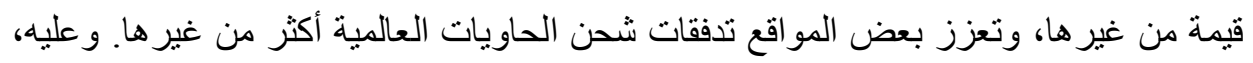

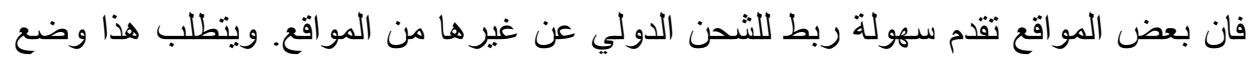

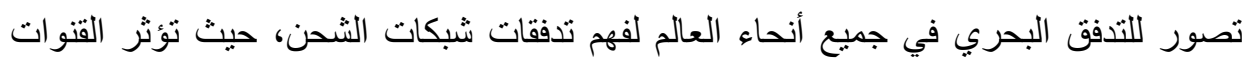

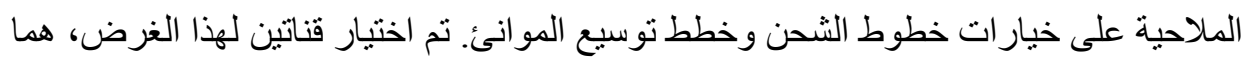

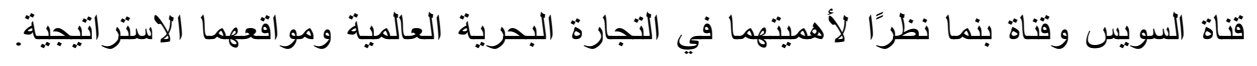

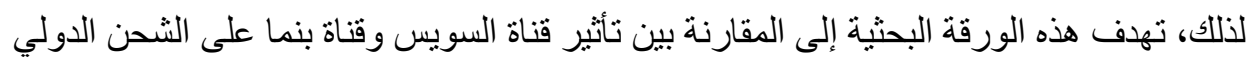

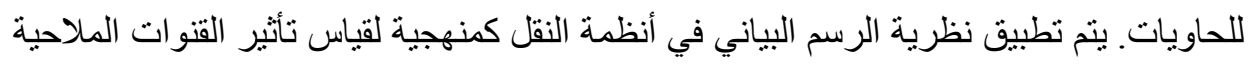

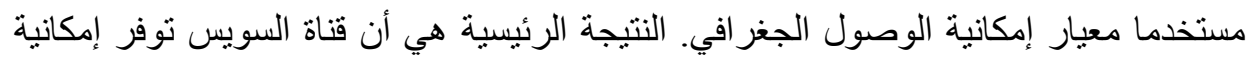

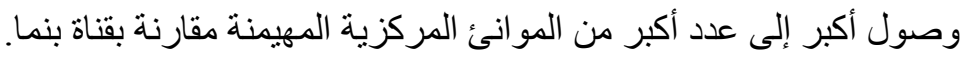
الكلمات الدالتشالمفتاحيتّ: قناة السويس، قناة بنما، مقياس سهولة الوصنة الوصول، مقياس الربط.
\end{abstract}

